\title{
Determination of Free Glycerol in Biodiesel Using UV-Visible Spectroscopy: a Validation Study
}

\author{
Nogueira, A. B.; * Gomes, W. E.; Sartori, D. S.; Mendes, R. K.; Etchegaray, A.
}

Rev. Virtual Quim., 2019, 11 (6), 1725-1736. Data de publicação na Web: 7 de outubro de 2019

http://rvq.sbq.org.br

\section{Determinação de Glicerina Livre em Biodiesel Utilizando Espectroscopia UV Visível: Estudo de Validação do Método}

Resumo: Concentrações elevadas de glicerina livre em biodiesel causam danos em motores. Pela legislação brasileira, (ANP Resolução 45/2014), o limite máximo permitido para glicerina livre em biodiesel é 0,02 \% em massa. A norma ASTM D6584 estabelece que o método padrão para se determinar glicerina livre em biodiesel é cromatografia gasosa, uma técnica demorada e cara. Como alternativa, a glicerina livre pode ser quantificada, após derivatização, por espectroscopia de absorção na região do UV-Visível $(410 \mathrm{~nm})$. No presente trabalho usamos o protocolo de validação para o método espectroscópico. Resultados indicam que o método é linear $\left(r^{2}=0.995\right)$ para o intervalo de concentrações estudado e possui exatidão e precisão aceitáveis. O método apresentou valores de desvio padrão relativos para repetibilidade e exatidão abaixo de 5,0 \%. Para o cálculo dos valores de limite de detecção e quantificação foram empregados três diferentes métodos. Dois deles apresentaram limites de quantificação apropriados para glicerina. Entretanto, o método proposto pelo INMETRO forneceu um valor maior para o limite de quantificação. Considerando que o método é baseado em reação química de derivatização, com parâmetro colorimétrico, a robustez do método foi analisada para pequenas alterações na reação em função da temperatura, do comprimento de onda e do material da cubeta. Os resultados mostraram que o método é robusto para pequenas variações na temperatura de reação, mas não é robusto para mudanças no comprimento de onda e para mudança de material da cubeta (plástico ou vidro).

Palavras-chave: Método de validação; biodiesel; Espectroscopia UV-visível.

\begin{abstract}
High glycerol content in biodiesel impairs engine performance. Brazilian legislation, (ANP Resolution 45/2014), limits the maximum of $0.02 \% \mathrm{w} / \mathrm{w}$ for free glycerol in biodiesel. The ASTM D6584 standard method for glycerol determination is gas chromatography, a time consuming and expensive technique. As alternative, free glycerol in biodiesel can be determined, after derivatization, by absorption spectroscopy in the visible region $(410 \mathrm{~nm})$. In this work, we have used a validation protocol for the spectroscopy method. Results indicate that the proposed method is linear $\left(r^{2}=0.995\right)$ for the studied concentration range and has acceptable accuracy and precision. The method presented relative standard deviations values of intermediate repeatability and accuracy below $5.0 \%$. To calculate the limits of detection and quantification, three different calculation methods were used. Two of them resulted in appropriate quantification limits for glycerol. However, for the INMETRO calculation method, we found a higher value of quantification limit. Considering that the method is based on a chemical derivatization reaction, to produce a color product, the robustness of the method was analyzed for small changes in reaction temperature, wavelength and type of cuvette used in measurements. The results have shown that the method is robust for small variations in the reaction temperature, but not for small changes in wavelength and type of cuvette used (glass or plastic cuvette).
\end{abstract}

Keywords: Validation method; biodiesel; UV-visible spectroscopy.

\footnotetext{
* Pontifícia Universidade Católica de Campinas, Centro de Ciências Exatas, Ambientais e Tecnologias, Faculdade de Química, Parque Rural Fazenda Santa Cândida, CEP 13087-571, Campinas-SP, Brasil.

Naleborin@puc-campinas.edu.br DOI: $10.21577 / 1984-6835.20190121$
} 


\section{Determination of Free Glycerol in Biodiesel Using UV-Visible Spectroscopy: a Validation Study}

\section{Alessandra B. Nogueira, Wyllerson E. Gomes, Danielle S. Sartori, Renata K. Mendes, Augusto Etchegaray}

Pontifícia Universidade Católica de Campinas, Centro de Ciências Exatas, Ambientais e Tecnologias, Faculdade de Química, Parque Rural Fazenda Santa Cândida, CEP 13087-571, Campinas-SP, Brasil.

*aleborin@puc-campinas.edu.br

Recebido em 17 de março de 2019. Aceito para publicação em 8 de agosto de 2019

\section{Introduction}

1.1. Free glycerol in biodiesel

1.2. Analytical validation

2. Materials and Methods

2.1. Materials

2.2. Selectivity

2.3. Sensitivity

2.4. Preparation of blank samples

2.5. Linearity

2.6. Analysis of biodiesel samples

2.7. Accuracy

2.8. Repeatability

2.9. Intermediate Accuracy

2.10. Robustness

\section{Results and Discussion}

3.1. Linearity and sensitivity

3.2. Sensitivity

3.3. Accuracy and precision

3.4. Robustness

\section{Conclusions}

1. Introduction
A snapshot of the global population in 2017 numbers the world's population to be nearly 7.6 billion. This implies that the world has added approximately one billion 
inhabitants over the past twelve years. ${ }^{1}$ The growth of the world's population has led to the expansion of the industrial and transport sectors, gradually increasing the demand for food and energy sources. ${ }^{2,3}$ The shortage of oil, coal and natural gas coupled with rising prices and a series of environmental problems caused by their combustion, demands a search for alternative energy sources that will partially or completely substitute fossil fuels. ${ }^{2,4,5}$ Under the conceptual view of NEXUS for cities, general efforts should focus on sustainable uses of water, food and energy to ensure that there will be enough resources for the generations. $^{6,7}$

To encourage the incorporation of biodiesel into the Brazilian energy matrix, the Federal Government, in 2004, created the National Program for the Production and Use of Biodiesel, which instituted Law 11,097, in 2005. The latter, states the intermediate addition of $2 \%$ of biodiesel (B2) in all diesel marketed domestically as of January 2008 and the percentage of $5 \%$ in the blend (B5) from the beginning of 2013. ${ }^{8,9}$ Since 2017, according to law 13.263/2016, the percentage is $8 \%$ of biodiesel B100 in volume. ${ }^{10}$

Biodiesel can be obtained from many renewable sources ${ }^{11}$ through different methods. ${ }^{12}$ Particularly, vegetable oil or animal fats $^{13}$ are the main sources for biodiesel production, by both interesterification reaction (between triglycerides and methyl acetate), ${ }^{14}$ and transesterification reaction ${ }^{15}$ (triglycerides reacting with methanol or ethanol under alkaline catalysis). The latter process presents higher yields, being thus more appropriate for industrial processes. ${ }^{5}$ The end products of this reaction produce a biphasic system. The oil phase (biodiesel) stays on the top layer, whereas the side-product (glycerol), which has a density of $1.3 \mathrm{~g} / \mathrm{mL}$, stays at the bottom phase. ${ }^{15-17}$

\subsection{Free glycerol in biodiesel}

An extremely important parameter for asserting the quality of biodiesel samples is the mass percentage of free and total glycerol. Glycerol in solution can be either dispersed (free) or an additional side-product of the transesterification reaction. ${ }^{17}$

The high content of free or bound glycerol in biodiesel can cause accumulation in fuel tanks, valve deposits, injector contamination, fuel lines. in short, a series of problems that may compromise the proper functioning of the vehicle's engine. In addition, above $180^{\circ} \mathrm{C}$, the combustion of glycerol together with biodiesel generates acrolein, which is toxic. $^{18}$

The resolution 45/2014 from ANP established through the maximum percentage of traces of free glycerol of $0.02 \% \mathrm{~m} / \mathrm{m}$ for all biodiesel that is commercialized in Brazil. ${ }^{18,19}$

The American Society of Tests and Materials released the technical standard ASTM 6584 to determinate the percentage of free and / or total glycerol in biodiesel using Gas Chromatography with flame ionization detection. $^{20}$

However, to attend several legislations around the world, alternative methods have being proposed to determinate the amount of biodiesel in fuels, as ${ }^{1} \mathrm{H}-\mathrm{NMR}$ and ATRFTIR. ${ }^{21-23}$

Determination of free glycerol by visible absorption spectrophotometry was proposed by Bondioli and Bella. ${ }^{24}$ Glycerol was extracted from the biodiesel and reacted with sodium metaperiodate. Under this conditions, glycerol is oxidized to form formaldehyde, iodate and formic acid. ${ }^{15,24}$ The method proposed is cheap, uses a small amount of sample and easy to handle.

\subsection{Analytical validation}

A method is considered validated after complying with all steps of the validation 
process. The main analytical parameters studied are: selectivity, linearity, sensitivity, limit of detection, limit of quantification, precision, accuracy and robustness. ${ }^{25-29}$

The aim of this work was to validate the method for free glycerol determination in biodiesel samples, using absorption spectroscopy in the visible region. In addition, to use the new method to evaluate the glycerol content in two biodiesel samples from two Brazilian companies located at Campinas (SP), Brazil.

\section{Materials and Methods}

\subsection{Materials}

The equipment used were: Ohaus Adventurer Pro Precision Scale, Chronometer, Vortex Phoenix V56, Ultrathermostatic Bath NT-281 Nova Técnica, Centrifuge Excelsa II Model 206 Fanem and HP UV / Vis Spectrophotometer Agilent 8453. The reagents used were glacial acetic acid (Nuclear), ammonium acetate (Vetec), ethyl alcohol (Chemco), sodium metaperiodate (Nuclear), acetylacetone (Merck), n-Hexane (Nuclear) and glycerol (Chemco).

\subsection{Selectivity}

No selectivity analysis was performed. The biodiesel samples were set free from all interferents before derivatization. The reaction product, 3,5 Diacetyl-1,4hydrolutidine absorbs at $410 \mathrm{~nm}$, which was selected for absorption measurements.

\subsection{Sensitivity}

To calculate the limits of detection (LD) and quantification (LQ), seven blank samples were prepared. Using the mean absorbance values of the blanks and the analytical curve, the LD and LQ were calculated in three different ways: by the equation of Ribani et al. ${ }^{27}$ by the method of Ribeiro et al. ${ }^{29}$ and by following INMETRO guidelines. ${ }^{26}$

\subsection{Preparation of blank samples}

The amount of $2.00 \mathrm{~mL}$ of working solvent (water: ethanol, 1:1) was added to test tubes. Then, $1.2 \mathrm{~mL}$ of sodium metaperiodate was added. The solution was stirred for 30 seconds. Acetylacetone $(1.2 \mathrm{~mL})$ was added. The tubes were heated at $70^{\circ} \mathrm{C}$ for 1 minute with manual stirring. After the reaction time, they were cooled to room temperature and absorption was determined at $410 \mathrm{~nm}$.

\subsection{Linearity}

For the linearity test, a calibration curve was constructed, in triplicate, containing seven points, from $9.0 \times 10^{-4} \mathrm{mg} / \mathrm{mL}$ to 6.3 $x 10^{-3} \mathrm{mg} / \mathrm{mL}$.

Using test tubes, $2.00 \mathrm{~mL}$ of each point of the analytical curve was added and the solutions were treated as described above.

\subsection{Analysis of biodiesel samples}

Two companies from Campinas (SP, Brazil) provided biodiesel samples; one sample each. In a $10 \mathrm{~mL}$ volumetric flask, $1.0 \mathrm{~g}$ of the biodiesel sample was weighed. Four $\mathrm{mL}$ of hexane were added. The flask was then treated with the working solvent (water: ethanol, 1:1). The contents were transferred to the test tube and sealed with a stopper. It was stirred for 5 minutes and centrifuged at 2,000 rpm for 15 minutes. After centrifugation the supernatant was removed using a Pasteur pipette. Upon extraction, exactly $0.5 \mathrm{~mL}$ of lower layer was transferred to a second test tube. $1.5 \mathrm{~mL}$ of working solvent and $1.2 \mathrm{ml}$ of $10 \mathrm{mmol} / \mathrm{L}$ Sodium 
Metaperiodate were added. The solution was treated as described above.

\subsection{Accuracy}

The accuracy analysis was performed by a recovery rate, consisting of the addition of free glycerol to the biodiesel sample provided by company 1 . Glycerol was added at three different concentration levels $(50,100$ and $150 \%)$, that is, at the final concentrations of $1.8 \times 10^{-3} \mathrm{mg} / \mathrm{mL} ; 3.6 \times 10^{-3} \mathrm{mg} / \mathrm{mL}$ and $6.3 \times 10^{-}$ ${ }^{3} \mathrm{mg} / \mathrm{mL}$.

\subsection{Repeatability}

For the repeatability, seven different analyzes of the biodiesel samples were performed by analyst number 1 . The results were evaluated by calculating the relative standard deviation (RSD) of the obtained absorbance values at $410 \mathrm{~nm}$.

\subsection{Intermediate accuracy}

For the intermediate accuracy, using the same method and equipment, the same biodiesel sample was also analyzed seven times, but by $t$ analyst number 2 . The intermediate precision was evaluated by comparing the relative standard deviations (RSD) between the two different analysis.

\subsection{Robustness}

For robustness measurements, Full Factorial Planning $2^{3}$ was used with a glycerol solution of $3.6 \times 10^{-3} \mathrm{mg} / \mathrm{mL}$ (corresponding to the midpoint of the analytical curve). Table 1 presents the factors studied in this planning. Table 2 shows the matrix associated to the factorial design experiments.

From the absorbance values obtained from all these eight tests, a normal probability plot was generated (Teófilo et al. $\left.{ }^{28}\right)$. This graph allowed us to infer how significant are the parameter changes for this study.

Table 1. Parameters for Full Factorial Planning $2^{3}$

\begin{tabular}{ccc}
\hline Parameter & Lower level (-) & Upper level (+) \\
\hline $\mathbf{1}$ - Wavelenght & $405 \mathrm{~nm}$ & 420 \\
$\mathbf{2}$ - Derivatization temperature & $67^{\circ} \mathrm{C}$ & $73{ }^{\circ} \mathrm{C}$ \\
$\mathbf{3}$ - Cuvette & Glass & Plastic \\
\hline
\end{tabular}


Table 2. Matrice of signals for the Full Factorial Planning $2^{3}$

\begin{tabular}{cccc}
\hline Essay & 1 & 2 & 3 \\
\hline 1 & - & - & - \\
2 & + & - & - \\
3 & - & + & - \\
4 & + & + & - \\
5 & - & - & + \\
6 & + & - & + \\
7 & - & + & + \\
8 & + & + & + \\
\hline
\end{tabular}

\section{Results and Discussion}

From the absorbance values (Figure 1), three analytical curves were obtained, each

3.1. Linearity and Sensitivity containing six points (Figure 2).

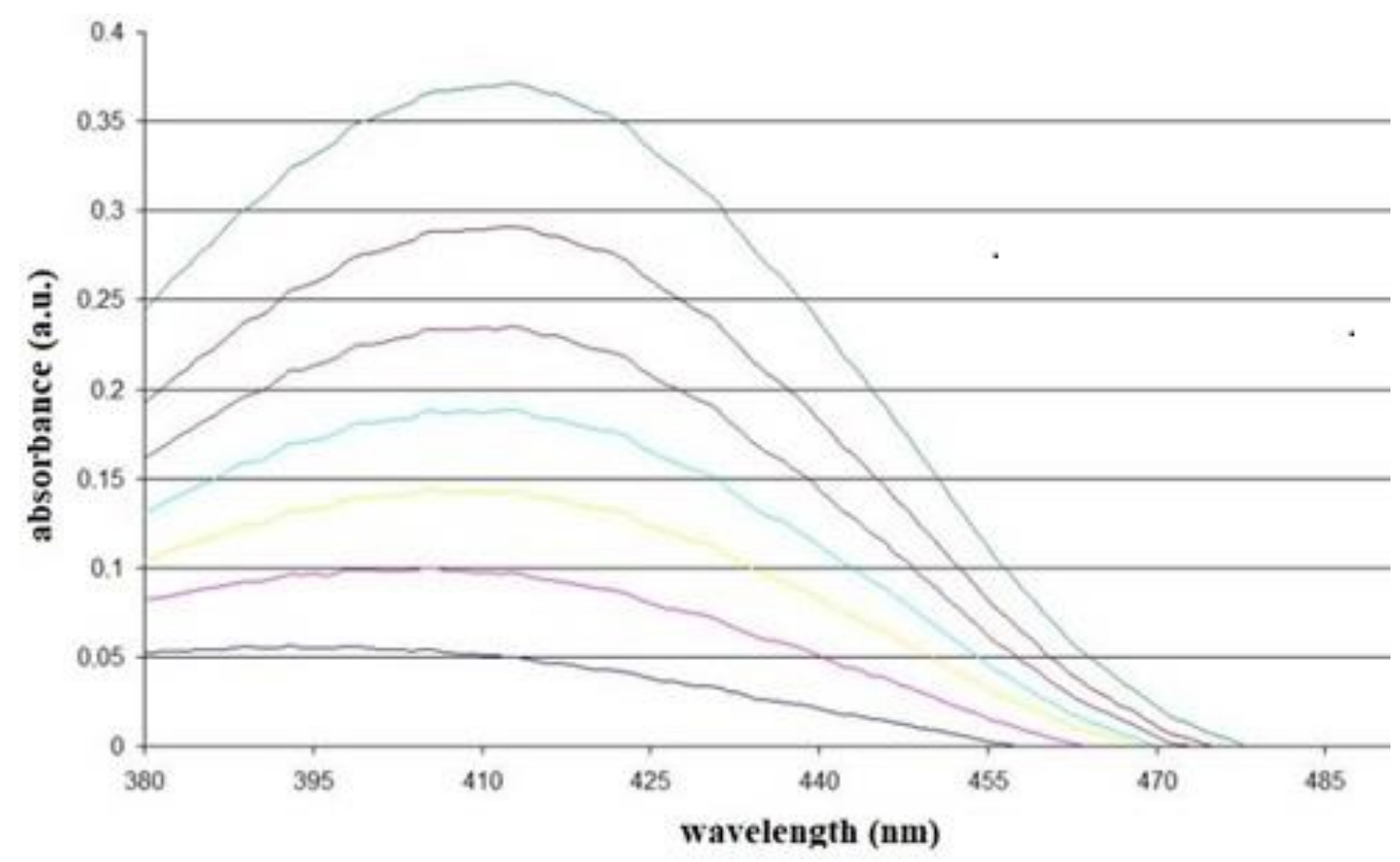

Figure 1. Set of spectra in the visible region $(380-500 \mathrm{~nm})$ for the reaction product 


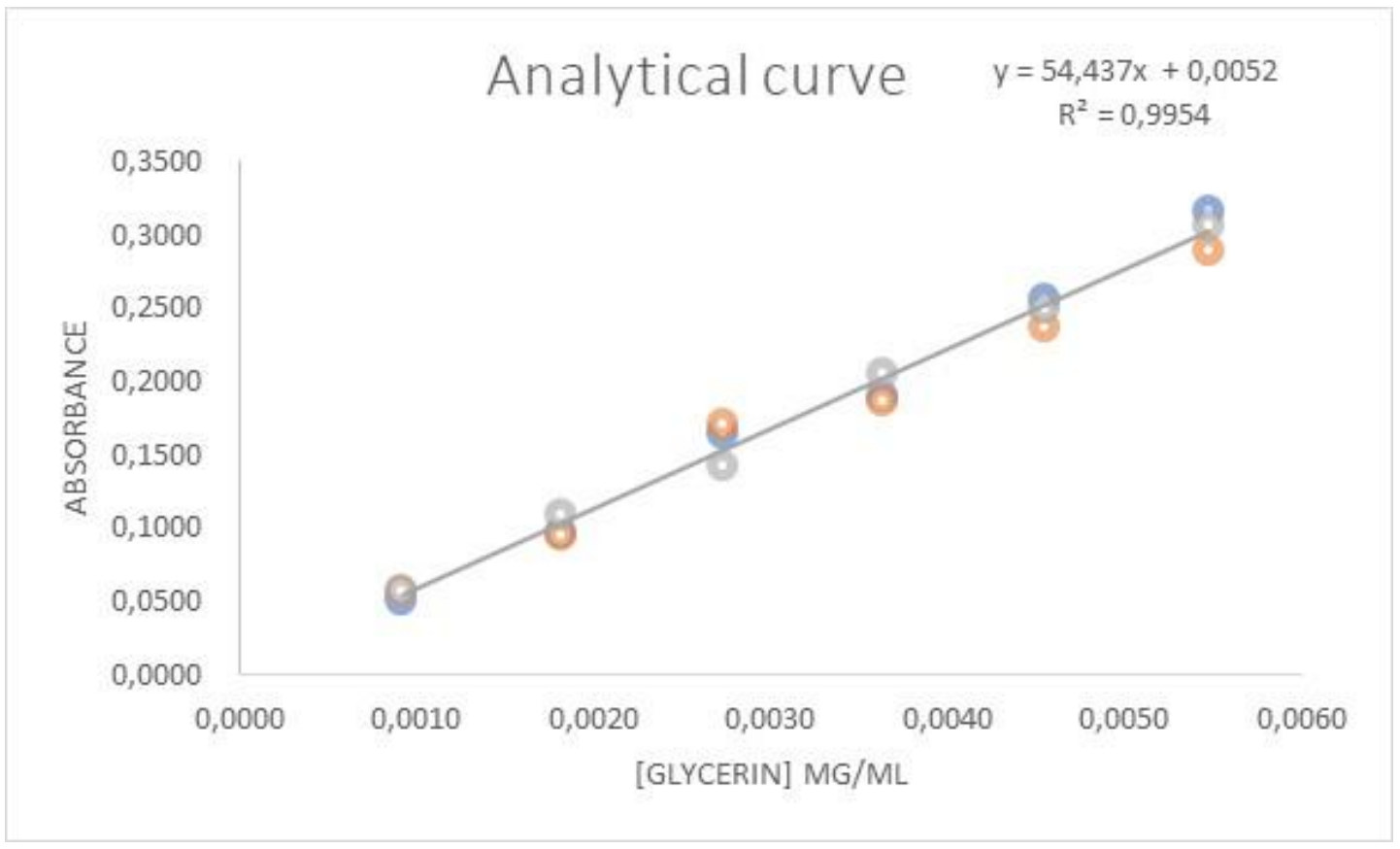

Figure 2. Calibration curves for the determination of free glycerol in biodiesel

Linear regression was applied to the standard curves to confirm the type of curve. The obtained correlation coefficient $\left(\mathrm{r}^{2}\right)=$ 0.9954 confirms that the analytical curve obtained corresponds to a straight line.
Table 3 shows that the linear regression model is statistically adjusted, since the specific value (F-calculated), of 1276.1 is higher than $F$ Table $\left(F_{1,4}\right)$ of 7.71 and the obtained coefficient of determination (variance explained) is $99.68 \%$.

Table 3. Analyses of Variance (ANOVA) in $95 \%$ confidence interval

\begin{tabular}{cccccc}
\hline Source & Sum of Squares & $\begin{array}{c}\text { Degrees of } \\
\text { Freedom }\end{array}$ & $\begin{array}{c}\text { Variance } \\
\text { estimate (mean } \\
\text { square) }\end{array}$ & $\mathbf{F}_{\text {cal }}$ & $\mathbf{F}_{\text {tab }}, \mathbf{4}$ \\
\hline Regression & 0.04231 & 1 & 0.04231 & 1276.1 & 7.71 \\
Residue & 0.00013 & 4 & $3.32 \times 10^{-5}$ & & \\
Total & 0.04244 & 5 & & \\
$\begin{array}{c}\text { \% Variance } \\
\text { explained } \\
\left(\mathrm{R}^{2}\right)\end{array}$ & 99.68 & & & & \\
\hline
\end{tabular}

Figure 3 presents the residuals plot, corresponding to the points of the curve, in connection to the linear model for standard curves. The random distribution, without trend and with the constant variation (homoscedasticity) is close to zero, demonstrating that the linear model is satisfactorily applied to this analytical curve. 


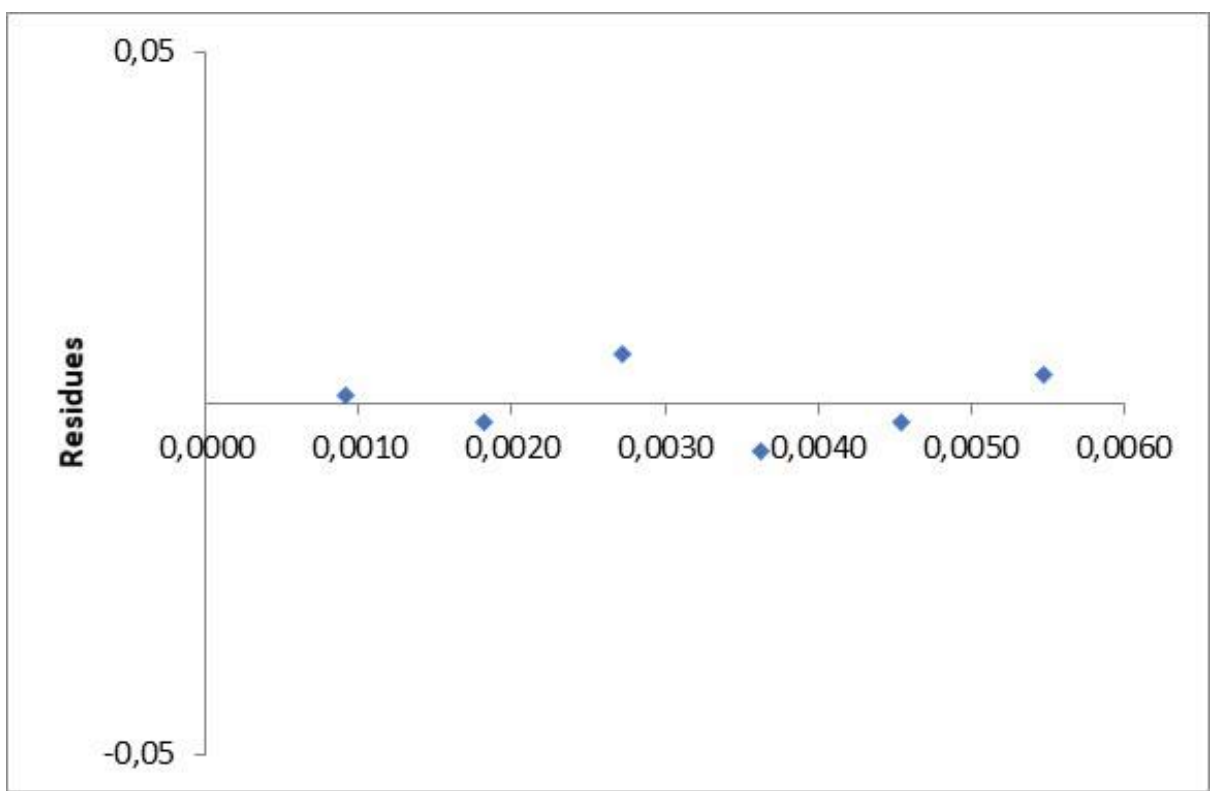

Figure 3. Residuals plot of the linear model analytical curve

Table 4 shows the concentrations of free glycerol for the biodiesel samples supplied by two companies from Campinas, SP (Brazil). The mean concentrations of glycerol were obtained by linear regression using equation $y=54.437 x+0.0052$, which was selected based on the coefficient of determination.

Table 4. Average concentrations of glycerol for biodiesel samples collected from two companies

\begin{tabular}{cccc}
\hline $\begin{array}{c}\text { Biodiesel } \\
\text { sample }\end{array}$ & $\begin{array}{c}\text { Average } \\
\text { Absorbance } \\
\text { (a.u.) }\end{array}$ & $\begin{array}{c}\text { Average Glycerol } \\
\text { Concentration } \\
\left(\mathrm{mg}^{\left.-\mathrm{mL}^{-1}\right)}\right.\end{array}$ & $\begin{array}{c}\text { Average Free } \\
\text { Glycerol } \\
\text { Percentage } \\
(\% \mathrm{~m} / \mathrm{m})\end{array}$ \\
\hline Company 1 & 0.305 & $5.29 \times 10^{-3} \pm 9.67 \%$ & $0.0230 \pm 0.009$ \\
Company 2 & 0.483 & $8.29 \times 10^{-3} \pm 2.02 \%$ & $0.0360 \pm 0.013$ \\
\hline
\end{tabular}

From the results presented in Table 3 we concluded that the biodiesel supplied by Company 2 presents a free glycerol content that is above the allowed limit of $0.02 \% \mathrm{w} / \mathrm{w}$.

\subsection{Sensitivity}

To evaluate sensitivity the limits of detection and quantification were calculated. There are different ways to calculate these limits depending on the regulatory body. Table 5 presents the LD and LQ using three different calculation methods. 
Table 5. Comparison of three different calculations methods for the limit of detection (LD) and limit of quantification (LQ)

\begin{tabular}{lccc}
\hline Reference & $(\text { RIBANI et. al., 2004) })^{27}$ & $\left.{ }^{(R I B E I R O ~ e t . ~ a l ., ~ 2008) ~}\right)^{29}$ & INMETRO $26^{26}$ \\
& $0.990 \times 10^{-3}$ & $1.29 \times 10^{-3}$ & $3.04 \times 10^{-3}$ \\
\hline $\mathrm{LD}(\mathrm{mg} / \mathrm{mL})$ & & $6.03 \times 10^{-3}$ \\
\hline
\end{tabular}

* table T Student within $99 \%$ confidence for 6 degrees of freedom: $t_{(7-1,99 \%)}$ is 3.143

By Comparing the results from the three calculation methods, the obtained values of LD and LQ differ substantially.

These parameters are calculated in different manners. INMETRO ${ }^{26}$ calculates LD and LQ using the signal obtained for the blank. Ribani et al. ${ }^{27}$ uses the standard deviation of the blank and the slope of the analytical curve to obtain the same parameters. RIBEIRO et $\mathrm{al}^{29}$ calculates LD and LQ from the deviation of the analytical curve.

Considering the LQ of $2.99 \times 10^{-3} \mathrm{mg} / \mathrm{mL}$ (Ribani) and $1.59 .10^{-3} \mathrm{mg} / \mathrm{mL}$ (Ribeiro) these may be considered appropriate LQ values since the sample concentration (within the range of $0.02 \%$ $\mathrm{m} / \mathrm{m}$ free glycerol) is $5.29 \times 10^{-3} \mathrm{mg} / \mathrm{mL}$.
However, in this work, the method suggested by INMETRO was used, which gave a LQ value of $6.03 \times 10^{-3} \mathrm{mg} / \mathrm{mL}$.

Therefore, using the Quantification Limit proposed by method of INMETRO, it is concluded that only those biodiesel samples that have a glycerol concentration higher than $6.03 \times 10^{-3}$ $\mathrm{mg} / \mathrm{mL}$, are statistically acceptable for analysis.

\subsection{Accuracy and precision}

The recovery rates for the accuracy analysis are presented in Table 6.

Table 6. Recovery rates calculated for the three studied levels.

\begin{tabular}{ccccc}
\hline Level & $\begin{array}{c}\text { Average } \\
\text { Absorbance } \\
(\text { a.u.) }\end{array}$ & $\begin{array}{c}\text { Glycerol Reference } \\
\text { Average }(\mathrm{mg} / \mathrm{mL})\end{array}$ & $\begin{array}{c}\text { Average Predicted } \\
\text { Glycerol }(\mathrm{mg} / \mathrm{mL})\end{array}$ & $\mathbf{T}(\%)$ \\
\hline $\mathbf{5 0 \%}$ & $0.403 \pm 0.002$ & $7.08 \times 10^{-3}$ & $6.94 \times 10^{-3}$ & 98.0 \\
$\mathbf{1 0 0 \%}$ & $0.422 \pm 0.031$ & $8.30 \times 10^{-3}$ & $7.28 \times 10^{-3}$ & 87.7 \\
$\mathbf{1 5 0 \%}$ & $0.573 \pm 0.021$ & $1.13 \times 10^{-2}$ & $9.82 \times 10^{-3}$ & 86.7 \\
\hline
\end{tabular}

According to INMETRO for concentrations ranging between 1 to $10 \mathrm{mg} / \mathrm{L}$, the recovery rate value should be between 80 and $110 \%$. In this work the sample concentration range was between 0.9 and $6 \mathrm{mg} / \mathrm{L}$. For the three levels analyzed, the recovery rate of the method was within the expected range, being $98.8,87.7$ and $86.7 \%$, respectively.

The results of the accuracy (repeatability and intermediate precision) are presented in Table 7. 
Table 7. Relative Standard Deviation (RSD) for repeatability and intermediate accuracy

\begin{tabular}{cc}
\hline Type of Accuracy & RSD (\%) \\
\hline Intermediate (2 analysts) & 2.02 \\
Repeatability & 4.76 \\
\hline
\end{tabular}

For precision analysis, the value of relative standard deviation (RSD\%) of the repeatability is expected to be less than that of the intermediate precision. However, the relative standard deviation (RSD\%) of the repeatability test was $4.76 \%$ and the intermediate precision was $2.02 \%$. Even with higher RSD value for repeatability, both values obtained can be considered acceptable (up to $5 \%$ ) since there is no relative standard deviation limit established for this analysis.

\subsection{Robustness}

For robustness analysis, considerable variations were observed between the measured absorbance values. To evaluate which variations were significant, the normal probability plot was produced (Figure 4).

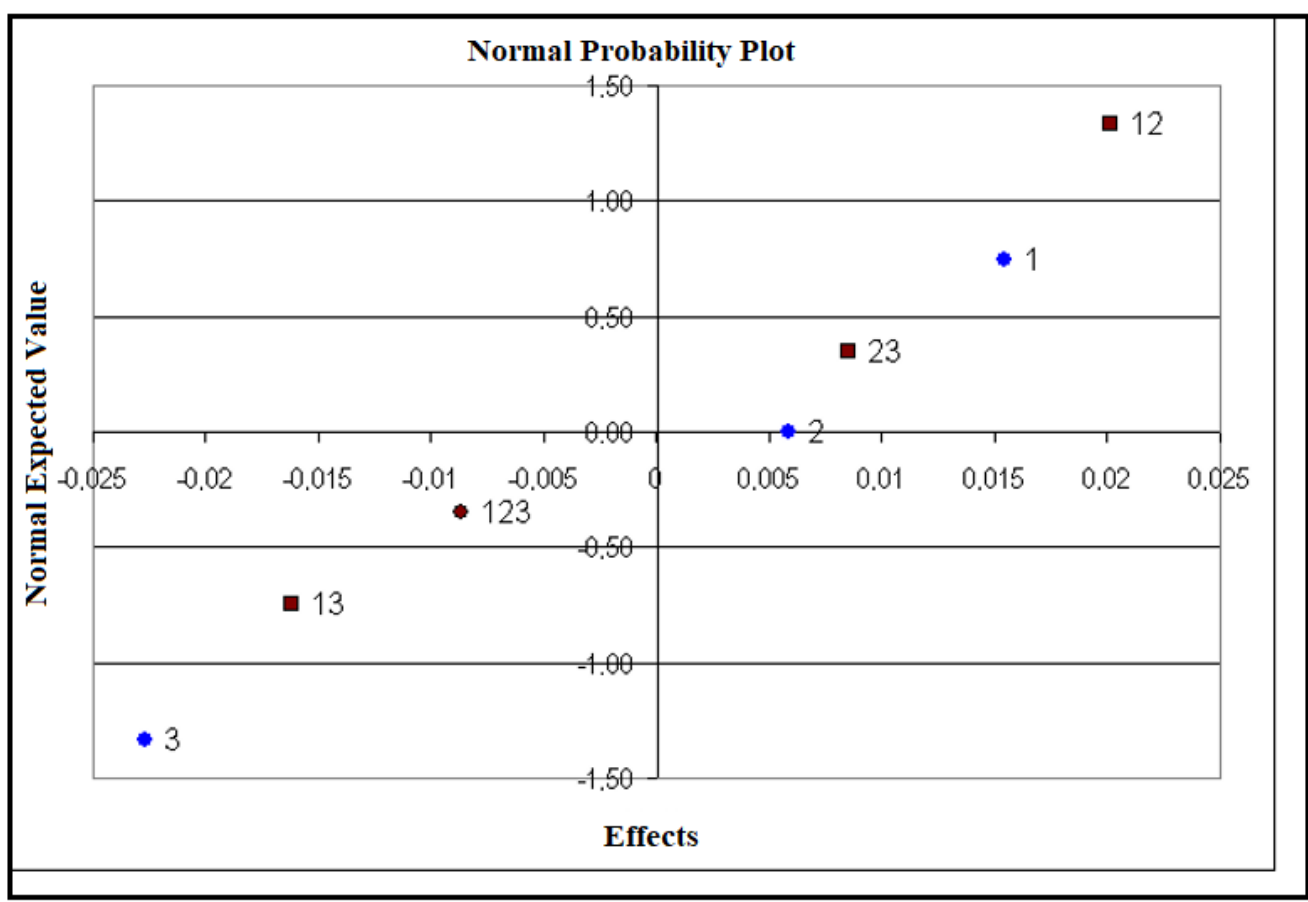

Figure 4. Normal Probability Plot indicating the effects of each factor in the robustness analysis of the method

In this graph one sees that the greater the distance from "zero point", the greater are the effects of the factors in contributing for the analysis' performance. For instance, point 12, which corresponds to the interaction between wavelength and temperature, and point 1 , which is related to the wavelength of analysis, are the ones that have significant effects on the analysis. The results demonstrate that they promoted positive 
changes. Yet, point 13 (interaction between wavelength and type of cuvette) and point 3 (type of cuvette) also provoked significant changes, which impact negatively on the analysis. On the other hand, point 2 (derivatization temperature) and point 123 (ternary interaction) show practically no effect on the analysis. Thus, changing the wavelength from $405 \mathrm{~nm}$ to $420 \mathrm{~nm}$ causes a positive effect, while changing the cuvette material from glass to plastic produces a negative response. Therefore, it is possible to infer that the small variation of wavelength and the material of the cuvette significantly alter the response. Consequently, the method is not robust for the variation of these two parameters. However, the parameter reaction temperature (derivatization reaction), either $67{ }^{\circ} \mathrm{C}$ or $73{ }^{\circ} \mathrm{C}$, does not significantly interfere with the response, i.e. for this parameter, the method is robust.

\section{Conclusions}

The method for determining glycerol by absorption spectroscopy in the visible region (410 nm) shows acceptable linearity and accuracy. Repeatability and intermediate precision did not exceed $5 \%$ of relative standard deviation. The limits of detection and quantification for two calculation methods are considered adequate. For the calculation of INMETRO, the LQ is not adequate. In the evaluation of the robustness, using experimental planning and normal graph it was also possible to conclude that the method is robust for small changes in temperature (67 or $73{ }^{\circ} \mathrm{C}$ ) of the derivatization reaction, but it is not robust for small changes in the wavelength or in the type of cuvette.

\section{Acknowledgements}

This study was financed in part by the Coordenação de Aperfeiçoamento de Pessoal de Nível Superior - Brasil (CAPES) - Finance Code 001.- scholarship PNPD (Gomes, W.E.). Danielle $S$. Sartori received a scholarship from PIBIC, CNPq.

\section{References}

${ }^{1}$ United Nations, Department of Economic and Social Affairs, P. D. World Population Prospects: The 2017 Revision, Key Findings and Advance Tables.; 2017. [Link]

${ }^{2}$ Owusu, P. A.; Asumadu-Sarkodie, S. A Review of Renewable Energy Sources, Sustainability Issues and Climate Change Mitigation. Cogent Engineering 2016, 3, 1. [CrossRef]

${ }^{3}$ Gerholdt, J.; Pandya, S.; Barrera, L.; International Council The Energy | Water | Food Nexus. Resources 2015; Vol. 2.

${ }^{4}$ Nejat, P.; Jomehzadeh, F.; Taheri, M. M.; Gohari, M.; Muhd, M. Z. A Global Review of Energy Consumption, CO2emissions and Policy in the Residential Sector (with an Overview of the Top Ten CO2emitting Countries). Renewable and Sustainable Energy Reviews 2015, 43, 843. [CrossRef]

${ }^{5}$ Gonçalves, E. D. L.; Ferreira, L. L. Flexible Use of Diesel or Biodiesel: An Approach Via Real Options. Brazilian Business Review 2008, 5, 218. [CrossRef]

${ }^{6}$ Kumar, P.; Saroj, D. P. Water-EnergyPollution Nexus for Growing Cities. Urban Climate 2014, 10, 846. [CrossRef]

${ }^{7}$ de Amorim, W. S.; Valduga, I. B.; Ribeiro, J. M. P.; Williamson, V. G.; Krauser, G. E.; Magtoto, M. K.; de Andrade Guerra, J. B. S. O. The Nexus between Water, Energy, and Food in the Context of the Global Risks: An Analysis of the Interactions between Food, Water, and Energy Security. Environmental Impact Assessment Review 2018, 72, 1. [CrossRef]

${ }^{8}$ Dias, M. A. de P.; Vianna, J. N. de S.; Felby, C. Sustainability in the Prospective Scenarios Methods: A Case Study of Scenarios for Biodiesel Industry in Brazil, for 2030. Futures 2016, 82, 1. [CrossRef]

Website ANP. Oil, Natural Gas and Biofuels Statistical Yearbook 2018. Available in: <http://www.anp.gov.br/publicacoes/anuari 
o-estatistico/oil-natural-gas-and-biofuelsstatistical-yearbook-2018>. Accesso em: 10 janeiro 2019.

${ }^{10}$ Website ANP. Biodiesel Production - Brazil $<$ http://www.anp.gov.br/dados-estatisticos $>$. Accesso em: 5 fevereiro 2019.

${ }^{11}$ Khola, G.; Ghazala, B. Biodiesel Production from Algae. Pakistan Journal of Botany 2012, 44, 379. [Link]

12 Uliana, N. R.; Palliga, M.; Quadri, M. B.; Oliveira, J. V. Continuous Packed-Bed Biodiesel Polishing Using Particulate Materials. Energy and Fuels 2017, 31, 627. [CrossRef]

${ }^{13}$ Conceição, M. M.; Fernandes, V. J.; Araújo, A. S.; Farias, M. F.; Santos, I. M. G.; Souza, A. $G$. Thermal and Oxidative Degradation of Castor Oil Biodiesel. Energy and Fuels 2007, 21, 1522. [CrossRef]

${ }^{14}$ Casas, A.; Ruiz, J. R.; Ramos, M. J.; Pérez, Á. Effects of Triacetin on Biodiesel Quality. Energy and Fuels 2010, 24, 4481. [CrossRef]

${ }^{15}$ Mota, C. J. A.; Silva, C. X. A. da; Gonçalves, V. L. C. Gliceroquímica: Novos Produtos e Processos a Partir Da Glicerina de Produção de Biodiesel. Química Nova 2009, 32, 639. [CrossRef]

${ }^{16}$ Monteiro, M. R.; Luis Kugelmeier, C.; Sanaiotte Pinheiro, R.; Otávio Batalha, M.; Da, A.; César, S. Glycerol from Biodiesel Production: Technological Paths for Sustainability. Renewable and Sustainable Energy Reviews 2018, 109. [CrossRef]

${ }^{17}$ Andrić, I.; Pina, A.; Ferrão, P.; Fournier, J.; Lacarrière, B.; Le Corre, O.; Nguyen Thoai, D.; Kumar, A.; Prasertsit, K.; Tongurai, C.; et al. Evaluation of Biodiesel Production Process by the Determining of the Total Glycerol Content in Biodiesel. Energy Procedia 2017, 138, 544. [CrossRef]

${ }^{18}$ Lôbo, I. P.; Ferreira, S. L. C.; Cruz, R. S. da. Biodiesel: Parâmetros de Qualidade e Métodos Analíticos. Química Nova 2009, 32, 1596. [CrossRef]

${ }^{19}$ Website ANP. Free Glycerol limit in Biodiesel Available $<$ http://legislacao.anp.gov.br/?path=legislaca o-anp/resol-anp/2014/agosto\&item=ranp45-2014> Accesso em: 5 fevereiro 2019.
${ }^{20}$ D6584/08, A. Standard Test Method for Determination of Free and Total Glycerine in B100 Biodiesel Methyl Esters by Gas Chromatography. 2008. [Link]

${ }^{21}$ Feng, Z. V.; Buchman, J. T. Instrumental Analysis of Biodiesel Content in Commercial Diesel Blends: An Experiment for Undergraduate Analytical Chemistry Journal of Chemical Education 2012, 89, 1561. [CrossRef]

${ }^{22}$ Da Rocha, G.; Colnago, L. A.; Moraes, T. B.; Zagonel, G. F.; De Muniz, G. I. B.; PeraltaZamora, P. G.; Barison, A. Determination of Biodiesel Content in Diesel Fuel by TimeDomain Nuclear Magnetic Resonance (TDNMR) Spectroscopy. Energy and Fuels 2017, 31, 5120. [CrossRef]

${ }^{23}$ Pisarello, M. L.; Maquirriain, M. A.; Querini, C. A. Free and Total Glycerin Analyses in Biodiesel-Diesel Blends. Energy and Fuels 2018, 32, 8431. [CrossRef]

${ }^{24}$ Bondioli, P. Nature of Some Insoluble Materials Recovered from Biodiesel Samples. European Journal of Lipid Science and Technology 2009, 111, 814. [CrossRef]

${ }^{25}$ Brito, N. M.; Júnior, O. P. de A.; Polese, L.; Ribeiro, M. L. Validação de Métodos Analíticos: Estratégia e Discussão. Pesticidas: Revista de Ecotoxicologia e Meio Ambiente 2003, 13, 129. [CrossRef]

${ }^{26}$ INMETRO. DOQ-CGCRE-008 Orientação Sobre Validação de Métodos de Ensaios Químicos; 2007.[Link]

${ }^{27}$ Ribani, M.; Grespan Bottoli, C. B.; Collins, C. H.; Fontes Jardim, I. C. S.; Costa Melo, L. F. Validação Em Métodos Cromatográficos e Eletroforéticos. Química Nova 2004, 27, 771. [CrossRef]

${ }^{28}$ Teófilo, R. F.; Ferreira, M. M. C. Quimiometria II: Planilhas Eletrônicas Para Cálculos de Planejamentos Experimentais, Um Tutorial. Química Nova 2006, 29, 338. [CrossRef]

${ }^{29}$ Ribeiro, F. A.L.; Ferreira, M.M.M; Morano, S.C.; Silva, L.R.; Schneider, R.P. Planilha de validação: uma nova ferramenta para estimar figuras de mérito na validação de métodos analíticos univariados. Química Nova 2008, 31, 164. [CrossRef] 